Relations industrielles

Industrial Relations

\title{
The Shoe Industry
}

\section{Gérard Tremblay}

Volume 5, numéro 5, février 1950

URI : https://id.erudit.org/iderudit/1023328ar

DOI : https://doi.org/10.7202/1023328ar

Aller au sommaire du numéro

Éditeur(s)

Département des relations industrielles de l'Université Laval

ISSN

0034-379X (imprimé)

1703-8138 (numérique)

Découvrir la revue

Citer cet article

Tremblay, G. (1950). The Shoe Industry. Relations industrielles / Industrial

Relations, 5(5), 43-46. https://doi.org/10.7202/1023328ar

Tous droits réservés @ C Département des relations industrielles de l’Université Laval, 1950

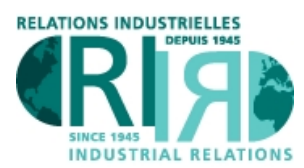

INDUSTRIAL RELATIONS
Ce document est protégé par la loi sur le droit d'auteur. L'utilisation des services d'Érudit (y compris la reproduction) est assujettie à sa politique d'utilisation que vous pouvez consulter en ligne.

https://apropos.erudit.org/fr/usagers/politique-dutilisation/ 


\title{
THE SHOE INDUSTRY
}

\author{
Gérard Tremblay
}

The last annual report of the parity committee of the shoe industry, covering the period from September 1, 1948, to August 31, 1949, provides us with a veritable mine of valuable unpublished information concerning both production and the relations between employers and employees.

For our province at least, where the committee has jurisdiction, it establishes precisely the number of productive units in each territorial zone determined by the decree relative to this industry, the number of workers employed there, and the wages paid.

\section{Production}

The statistics of the Department of Commerce at Ottawa show that in 1948 the total production of pairs of shoes in Canada reached 32,326,766, of which Quebec produced $19,580,637$, i.e. $60.5 \%$, and Ontario $12,048,679$, i.e. $37.2 \%$.

In 1937, two years before World War II, Canadian production reached a total of $24,325,355$. That of Quebec was $15,462,603$, or $63.56 \%$, and that of Ontario $8,357,412$, or $34.35 \%$.

As for the value of this production, in 1948 the total for Canada was $\$ 104,665,327.00$, of which Quebec's share was $\$ 63,533,871.00$ or $60.7 \%$, and Ontario's $\$ 36,973,103.00$ or $35.3 \%$.

In 1937 the value of Canadian production was only $\$ 40,905,216.00$. Quebec: $\$ 24,772,574.00$ or $60.5 \%$. Ontario: $\$ 14,597,082.00$ or $35.5 \%$.

We easily conclude from these figures that Quebec and Ontario control above $95 \%$ of the production, both in number of pairs and in value, of the Canadian shoe industry, and that of this Quebec accounts for nearly two thirds and Ontario one third.

If we study the statistics for the decade between 1938 and 1948 we find that this proportion between the respective production figures of the two industrial provinces is maintained without appreciable variation.

\section{The decree}

Management-labour relations in the shoe industry have been stabilized for a long time, fifteen years or so, which is the time when collective agreements, rendered obligatory by decrees imple- menting the Collective Agreement Act, were negotiated between employers' and workers' organizations. The first agreements had as signatories, on the part of the employers, individual manufacturers and the Association des manufacturiers de chaussures de Québec; on the part of the workers, some labor unions in the shoe industry. Later on the Association rurale des manufacturiers de chaussures became a co-signatory.

The employers, compelled by the exigencies of collective bargaining, formed some years ago the Association patronale des manufacturiers de chaussures $d u$ Québec which includes pratically all the manufacturers of the province. The workers, on the other hand, maintained their plurality of unions, and we note as signatories the Fédération nationale du cuir et de la chaussure du Cana$d a$ inc., The Boot and Shoe Workers' Union, and the Association des travailleurs en chaussures inc.

The industrial jurisdiction of the decree is determined by article $I$ of the order-in-council \#3003, of July 31,1946 , which reads as follows:

"The shoe industry comprises the manufacture, in whole or in part, of shoes of all types and descriptions and of any material, whether or not this manufacture constitutes the principal business of the firm or only a sideline; it also comprises the fabrication or construction of material used in the manufacture of shoes, any operation whatever performed on it, in any industrial establishment".

The decree covers the whole province; however, it had to take account of the economic conditions of different regions for establishing wage rates as implied by the remainder of article 6 of the Collective Agreement Act. The province is therefore divided into three zones:

Zone I: The island of Montreal and the territory comprised within a radius of five (5) miles from its limits;

Zone II: The City of Quebec and the territory comprised within a five (5) mile radius of its limits;

Zone III: The whole province of Quebec, with the exception of zones I \& II.

The wage rate calls for a differential of $5 \%$ between zones I and II, and of $15 \%$ between zones I and III. 
The decree calls for six (6) classes of workers. The minimum hourly rates for pieceworkers are the following:

$\begin{array}{ccc}\text { (Zone I) } & \text { (Zone II) } & \text { (Zone III) } \\ \$ 1.045 & \$ 0.99 & \$ 0.915 \\ .88 & .835 & .77 \\ .77 & .73 & .67 \\ .605 & .57 & .53 \\ .44 & .42 & .385 \\ .385 & .365 & .335\end{array}$

The last two classes obviously comprise those operations requiring only a minimum of competence.

\section{Distribution of factories}

At September 1, 1949, the province counted 207 shoe manufacturing establishments: zone I, 88; zone II, 34; zone III, 85.

It is interesting to note the variations in the number of factories per zone since 1936. This variation can show us whether the decree has been a stabilizing factor in the industry or if, on the contrary, it has unduly favored the region of Montreal, that of Quebec, or the rural zones. The following table shows the geographical distribuof shoe manufacturing establishments for the period of $1936-37$ to $1948-49$ :

$\begin{array}{lcccc} & \text { Zone I } & \text { Zone II } & \text { Zone III } & \text { Total } \\ 1936-37 & 64 & 33 & 52 & 149 \\ 1937-38 & 71 & 41 & 55 & 167 \\ 1938-39 & 69 & 33 & 56 & 158 \\ 1939-40 & 66 & 29 & 54 & 149 \\ 1940-41 & 71 & 26 & 52 & 149 \\ 1941-42 & 74 & 27 & 46 & 147 \\ 1942-43 & 69 & 24 & 47 & 140 \\ 1943-44 & 68 & 24 & 48 & 140 \\ 1944-45 & 70 & 27 & 62 & 159 \\ 1945-46 & 87 & 31 & 79 & 197 \\ 1946-47 & 93 & 34 & 97 & 224 \\ 1947-48 & 93 & 37 & 86 & 216 \\ 1948-49 & 88 & 34 & 85 & 207\end{array}$

We have already indicated that zone I comprises the island of Montreal and a five (5) mile radius; zone II, Quebec and a five (5) mile radius; zone III, the rest of the province.

We note with interest that from the territorial point of view zone III covers thirty-nine (39) municipalities distributed through the eastern counties, in the valley of the Chaudière, in the valley of St. Maurice and also that of Lake St. John. ${ }^{1}$

\section{The labour market}

The number and distribution of the factories do not indicate the importance of their production. To appreciate that we must have recourse to the figures for the numerical distribution of the labour force. In 1949 the industry counted 16,051 employees, of whom 13,285 were regularly employed: zone I, 8,694 employees (men - 4,720, women 3,974 ); zone II, 3,367 (men - 1,808, women 1,559 ); zone III, 3,990 (men - 2,151, women 1,839). These statistics indicate that women make up $45 \%$ of the employed labour. They reveal, moreover, that the greater part of the production, a little more than $50 \%$, takes place in Montreal, the region of Quebec and the rural zones dividing the other half.

The report of the committee groups the factories for each zone according to the number of employees, dividing the factories into little establishments employing from 1 to 10 workers, middle-sized establishments with 10 to 25 workers, and those employing 25 workers or more. The distribution (on which we will comment in our conclusions) is shown in the following table:

\begin{tabular}{|c|c|c|c|c|}
\hline Employee & $1-10$ & $10-25$ & 25-more & Total \\
\hline \multirow{2}{*}{ Zones: I } & 9 & 15 & 64 & 88 \\
\hline & 6 & 5 & 23 & 34 \\
\hline \multirow[t]{2}{*}{ II } & 30 & 18 & 37 & 85 \\
\hline & 45 & 38 & 124 & 207 \\
\hline
\end{tabular}

\section{Working conditions}

Here we limit our observations to working hours and wages. The average work hours per week for the year 1948-49 were 32.5 . The decree establishes a work week of forty-eight (48) hours with time-and-a-half for all overtime. However, since the immense majority of workers are paid on a piecework basis, the limit set to the weekly totai of working hours does not operate except in certain particular cases. Besides, as we noted above, the actual average work week for the year just expired was only 32.5 hours. From 1937-38 to 1948-49 the working hours per week were as follows:

(1) Luceville, Trois-Pistoles, Roberval, Chicoutimi, Bagotville, Lac St. Charles, Notre Dame des Laurentides, Giffard, Loretteville, St. Emile, Huron Village, Sillery, Qué., Ste. Marie, Valley Jct., Beauceville, St. Georges, St. Samuel, Lac Mégantic, Sherbrooke Richmond, Victoriaville, Plessisville, St. Tite, GrandMère, Ste. Geneviève, Three Rivers, Lavaltrie, Contrecoeur, Upton, Acton Vale, St. Joseph de Yamaska, St. Hyacinthe, St. Pie, Marieville, St. Césaire, St. Rémi, Terrebonne, St. Jérôme, L'Assomption 


\begin{tabular}{|c|c|}
\hline $\begin{array}{lllll}. . & . . & \ldots & . . & 29.75\end{array}$ & $\begin{array}{lllll}\ldots & \ldots & \ldots & & 38.2\end{array}$ \\
\hline $1938-39$ & 1944-45. \\
\hline $1939-40$. & $1945-46$. \\
\hline $1940-41$. & $1946-47$ \\
\hline $1941-42$. & $1947-48$ \\
\hline $1942-43$ & $1948-49$ \\
\hline
\end{tabular}

We note that the industry realized its maximum output in the year 1942-43 with an average work week of 41.8 hours. The work was almost equally distributed among the three zones for the year 1948-49, the weekly average being 32.8 hours in zone I, 31.3 hours in zone II, and 33 hours in zone III.

As to wages, the total for the province was $\$ 15,973,461.09$. The wages paid in zone I were $\$ 9,673,842.24$; in zone II, $\$ 2,726,9.38 .11$; in zone III, $\$ 3,572,680.74$.

It is useless to say that the total of wages has been constantly growing, due to the augmentation of the number of workers and of production as well as to the increase in wage rates properly speaking. For the year 1937-38 the committee fixed an index of 100 for reckoning total wages; the following table shows the changes in this total wage index for the subsequent years:

\begin{tabular}{|c|c|c|}
\hline $1937-38$ & 100 & $1943-44 \ldots \ldots . . . . .193 .1$ \\
\hline 1938-39 & 102.7 & $1944-45 \ldots \ldots$ \\
\hline 1939-4 & 110.9 & $1945-46$. \\
\hline $1940-41$ & 131.4 & $1946-47 \ldots$ \\
\hline $1941-4$ & 166 & $1947-48$ \\
\hline $1942-43$ & 186.9 & $1948-49$ \\
\hline
\end{tabular}

The report does not indicate the average wage of the workers. Moreover, the average wage would not be equitable for the industry, given the fact that the industry comprises a multiplicity of operations some of which require a high degree of skill, while others, especially classes 5 and 6 as determined by the decree, require very little of it.

The commitee did well, however, in indicating the wage average for some categories. Thus, for zone I, the wage for leather cutters working by the piece was $\$ 1.23$ whereas the rate for those working by the hour was $\$ 1.049$; for zone II, $\$ 1.12$ and $\$ .944$; for zone III, $\$ 1.048$ and $\$ .885$. The wage average for the whole province was $\$ 1.099$.

The report indicates the average hourly wages for the sewing department, the sole leather department, the lasting, making and finishing de- partments. For certain major operations the wage average in the province attained in 1949 a level of $\$ 1.24$ per hour - as compared with $\$ 1.16$ in 1947 $48, \$ 1.01$ in $1946-47$, and $\$ .614$ in the year preceeding the war, i.e. 1938-39. Major operations include the work of the stitchers, fitters, toe pullers, sole leather cutters, edge trimmers and buffers. The following interesting table indicates the annual average of wages payed for the last decade to workers of the class I designated in the decree, by fourteen (14) typical factories of the province:

\begin{tabular}{|c|c|}
\hline $1938-39 \ldots \ldots 1,213.80$ & $1944-45 \ldots$ \\
\hline $1939-40 \ldots \ldots 1,282.50$ & .. .. $1,991.37$ \\
\hline $1940-41 . . . . .1,584.51$ & $1946-47$. \\
\hline $1,775.41$ & $1947-48$ \\
\hline $1942-43 . \ldots .2,051.88$ & $1948-49$ \\
\hline
\end{tabular}

$1943-44 \ldots$.. . 1,968.66

We see that wages have practically doubled for these skilled workers.

Let us add, finally, that the industry now grants workers two (2) weeks of paid leave of absence, one of which takes place during the course of the summer and the other during the holidays.

\section{Conclusions}

The conclusions we may draw from this annual report are of definite interest.

1. The shoe industry is rooted mainly in Quebec. The value of the production in our province attained $60.7 \%$ for the year 1948. In 1937 the percentage was 60.5 .

We can observe the same stability in the province of Ontario. There the output for 1948 was $35.3 \%$ of the national total. In 1937 it was $35.5 \%$.

The relative positions of both provinces have remained the same, and the shoe industry has not been able to take root in the western or eastern provinces where the entire production attained less than $5 \%$ of the total for all the provinces together.

This stability warrants the conclusion that costs have not increased disproportionately either in Quebec or Ontario; otherwise a center of appeal would have been set up in one or the other province. Wages, which constitute a primary element of costs in the shoe industry, have therefore been stabilized, thanks to the decrees enacted in implementation of the Collective Agreement Act. 
2. In the province of Quebec itself, an equilibrium has been established between zones I, II and III. No zone seems to have suffered a notable regression in its activities. In 1949 zone I contained 88 establishments as compared with 64 in 1937; zone II, 34 as compared with 33 ; zone III, 85 as compared with 52 .

Only zone II (Quebec) does not appear to be progressing in number of factories. It is of note that the rural zone has climbed from 52 establishments to 82 and that the arithmetical proportion here is of a greater dimension that in zone I. We must conclude from this that the contracting parties of the collective agreement acted prudently in setting up the wage differentials of $5 \%$ and $15 \%$ between zone I and zones II and III. The rural industry, far from disappearing, as it was believed it would do at once in certain areas, spread to thirty new centers.

3. There are 9 small firms in Montreal (1 to 10 paid employees), 6 in Quebec, and 30 in the other centers. Evidently the small firms develop more readily in the smaller centers of population.

The middle-sized firms ( 10 to 25 paid workers) show an almost identical development in each zone: 15 in Montreal, 5 in Quebec, and 18 in the other centers.

The third category of establishments ( 25 or more paid workers) are represented by 64 factories in Montreal, 23 in Quebec, and 37 in the smaller centers.

It is worthy of note, therefore, that the industry can achieve a high level of production as easily in the rural municipalities of medium population as in the big cities.

The decree does not seem to have had any bad effect in this regard. On the contrary, it appears that it has permitted private enterprise to develop according to its own taste and initiative.

If on the one hand the large metropolitan centers benefit from a more abundant labour supply, from proximity to the sources of raw materials and machinery, from transport facilities, from less expensive telephone communications, on the other hand the small centers are compensated by the differential of $15 \%$ in the wage rates in relation to zone I, and, it must be noted, by a greater stability of the labour force.

4. Collective bargaining and mixed commissions became, more than a decade ago, the accepted custom in the shoe industry. The result is that the industry has been quite definitely marked by calm and peaceful domestic relations. Representatives of management and labour, meeting each month to discuss their common problems, have been able to resolve practically every social and economic difficulty.

Note that the presence of labour unions obliged the employers to establish unity in their ranks by their own union. It is for that reason that they set up the Association patronale des manufacturiers de chaussures du Québec, which bands together nearly all the manufacturers.

5. The rates fixed by the decree, we shall see, are really minimum rates, and were often exceeded. Thus, for leather cutters the minimum hourly wage provided by the decree is $\$ 1.045$ for zone I, $\$ .99$ for zone II, and $\$ .915$ for zone III (i. e. piecework rates). The real hourly wage average for these same workers was $\$ 1.23$ for zone I, $\$ 1.12$ for zone II, and $\$ 1.048$ for zone III. We could add other facts of the same nature which can be deducted from this parity committee's report. It is clear from this that the decree does not, as a matter of fact, establish absolute minimum rates, for they are always surpassed, thanks to the increased output of the workers who, because of the device of piecework pay, get first benefit from the returns.

6. We see, likewise, that the average number of hours for the week was 32.5 for the year 1948-49. A guaranteed wage, if it is ever demanded, cannot go much beyond the pay of a 30 hour week in this industry. Like every statistical average this does not give a real picture of the situation in the industry. The shoe industry has its own slumps, its ups and downs of production, provoked by hazards of weather, by the caprice of fashions in footwear, and by the dependance of Canadian styles on the American.

To sum up, we may say that the shoe industry, as far as labour relations are concerned, enjoys stability in our province, thanks to the collaboration of workers' and employers' organizations. Taking all things into consideration, we have practically achieved social peace. After a hard apprenticeship a sound technique of industrial relations has been established, and, to the men of good will who developed it, it gives results for which we can well afford to join them in rejoicing. 